\title{
Relationship between Consciousness about Environmental Education Concepts in Secondary School Chemistry Curriculum and Attitude of Students toward the Environment in Kwara State
}

\author{
Olabode Osunji* \\ Department of Science Education, School of Science and Technology Education, Federal University of Technology, Minna Niger State, Nigeria
}

*Corresponding Author: osbod200@hotmail.co.uk

\section{ABSTRACT}

The study aimed to investigate the relationship between consciousness about environmental education (EE) concepts in senior secondary school chemistry curriculum and the attitude of Nigerian chemistry students toward the environment. The study utilized a descriptive survey design using simple random sampling and stratified proportionate sampling techniques. A sample of 400 senior secondary school science students from the 18 senior secondary schools participated in the study. Two structured questionnaires "Students Attitude to Environment Questionnaire" (SAEQ) and "Students Consciousness toward Environment Questionnaire" (SCEQ) were developed by the researcher. The validity coefficient of the SAEQ and SCEQ was 0.801 and 0.765 , respectively. Three research questions and three null hypotheses guided the study. Data collected were analysis using mean standard deviation, one-way analysis of variance, and Pearson product moment correlation. The findings from the study revealed that the student environmental consciousness influenced their attitude toward the environment and that students' continuous exhibition of attitude toward the environment was rooted in their inadequate consciousness or knowledge of the causes and effects of environmental problems. As a result of this research, it is recommended that the Ministry of Education updates the curriculum of senior secondary school managing EE content.

KEY WORDS: attitudes; education; environment; chemistry; consciousness

\section{INTRODUCTION}

$\mathbf{E}$ nvironmental problems touch every nation and adversely affect the lives and health of their populations (UNEP, 2012). These environmental problems can be grouped into natural and artificial types, but it was found that the most serious and reoccurring environmental problems were artificial such as pollution, deforestation, overfishing, ozone layer depletion, and wildfire (Chinedu, 2008).

Environmental education (EE) is the process of helping people through formal and non-formal education acquire understanding, skills, and values that will enable them to participate as active and formal citizens in the development of an ecologically sustainable and socially just society (Ononugbo, 2005). This implies that inadequate environmental ethics, ignorance or inadequate environmental awareness, knowledge, skills, and actions can be addressed through education. According to Olusanya (2006) in Nigeria, the early 1980s witnessed the growth of concern for environmental issues particularly at the non-formal level with setting up of the Nigeria Conservation Foundation (NCF). The concern became stronger with the dumping of toxic waste in Koko, a village in the then Edo state of Nigeria in 1987, as discussions and concerns for natural and physical environment, which use to be treated as esoteric, assumed national prominence.
It has been argued that this singular event set the tone for the development of EE in Nigeria (Olusanya, 2006).

Our environment is bedeviled by problems and this is gradually attracting the attention of the federal government and even nongovernmental organizations, such as World Commission for Environment and Development (WCED, 2018). For example, one of the major problems facing the Kwara state which has become an intractable nuisance is open and indiscriminate dumping of street litter. As a result of peoples' bad habit of throwing solid and liquid wastes carelessly from moving automobile vehicles and while walking on the streets by hawkers, there is an esthetic value depletion of the urban land scape. It has been reported, solid waste generation has been encouraged by the rapid increase in population, changes or improvement in wages, massive expansion of the urban areas, and the changing lifestyle or better standard of living as well as improvement in technology (UNESCO, 2007). Importantly for this study, the Kwara state has overtime experienced rapid urbanization, sprawling settlements, and rapid population growth, which, in turn, have the effect of increasing the generation of solid waste (UNESCO, 2005).

According to Adelagan (2016), waste can be defined as any material lacking direct value to the producer and so must be disposed of; similarly, waste is any material that is thrown away as unwanted. Nigeria Demographic and Health Survey 
(NDHS) (2004) emphasized the poor sanitation coverage in different Nigerian settlement types (urban, semi-urban, and rural areas) attributed to a number of factors including lack of consciousness, poor planning, poor funding, poor implementation of sanitation programs by different agencies, and above all, the absence of a clear-cut national or state policy on sanitation as well as inefficient management and EE.

EE can be argued to be an essential part of every student's learning. It helps to encourage consciousness of the environment, leading to informed concern for and active participation in resolving environmental problems. Through EE, it is believed that students should be able to find a mechanism where clean environment will be adequately enhanced through consistent day-to-day increase in the knowledge of emerging environmental problems.

In particular to this study, chemistry students should be adequately equipped intelligently, emotionally, and with the necessary manipulative skills that will help them to meet the challenges posed on them by both the present and the future environment. Chemistry plays an important role in our lives, there are five major categories in chemistry, which are related to materials, carbon-containing materials, theory and physical phenomena, chemistry of living process, and identification and quantification of chemical process (Manahan, 2006). The misuse of chemistry can harm the environment. Thus, chemistry needs to be the heart of solving the environmental issue.

Chemistry curriculum is considered to be an integral part of an educational system (Abdullah, 2013). For chemistry to attract the interest of students, its experimentation and discovery must be real, motivating, and embed attitudes in the learning and teaching process. This develops chemistry students through an educational process that creates consciousness, develops positive attitudes, and builds capacity and willingness to take action as an individual and as a group (Toili, 2007).

EE through chemistry teaching would, therefore, be an intervening mechanism of teaching students about the world events and the laws that govern man's existence. Students must be active, creative, and learn in ways natural to them to grasp the understanding of the natural phenomenon around them.

\section{Statement of the Research Problems}

There has been more than enough environmental harm in Nigeria as a result of continued interaction and interdependence between man and the environment which include bush burning, pollution, grazing, and careless use of technology over the years (Jekayinfa and Yusuf, 2004). Various studies such as Adedayo and Olawepo (1997), and Aina (2012), have been carried out on the desirability of EE and its integration into the school curriculum. Studies have been carried out in some parts of Nigeria such as Lagos, Oyo, Cross River, Kaduna, and Imo states to examine students' consciousness and attitude toward environmental problems as a result of school instructions (Aina, 2012). The major concern of this study is that it appears that the magnitude or degree of such environmental problems (soil erosion, water, land and air pollution, land degradation, deforestation, and flooding among others) is higher and more destructive in the Kwara state (Jekayinfa and Yusuf, 2004).

The most common environmental problem in the Kwara state is pollution. This pollution is through the dumping of waste refuse, burning of waste or coal, and industrial discharge among others. This is most prominent in the larger towns of the Kwara state (Offa, Ilorin, Iloffa, Omu-aran, Ajasse-ipo, and Lafiagi) (Kwara State Waste Management Council, 2007). The growth and development of industries and urbanization has contributed greatly to the excess carbon monoxide produced by combustion and other human activities in Kwara. This study examined the relationship between consciousness about EE concepts in senior secondary school chemistry curriculum and the attitude of students toward the environment in Kwara.

\section{Aims and Objectives of the Study}

The objectives of the study were to determine:

1. The level of consciousness about EE concepts in chemistry curriculum by senior secondary school students.

2. The attitude chemistry students possess toward the environment in Kwara.

3. The level of consciousness about EE concepts in chemistry curriculum among male and female students in senior secondary school in Kwara.

4. The kind of attitude male and female chemistry students possess toward the environment in Kwara.

5. Whether there is relationship between consciousness about EE concepts in chemistry curriculum and attitude toward the environment among SS1, SS2, and SS3 senior secondary school students in Kwara.

\section{Research Questions}

The study sought answers to the following research questions:

1. Would there be any relationship between consciousness about EE concepts in senior secondary school chemistry curriculum and attitude of chemistry students toward the environment in Kwara?

2. Is there any relationship between male students' consciousness about EE concepts in chemistry curriculum and male students' attitude toward the environment among senior secondary school students in Kwara?

3. Would there be any relationship between consciousness about EE concepts in chemistry curriculum and attitude toward the environment among SS1, SS2, and SS3 senior secondary school students in Kwara?

\section{Research Hypotheses}

The following null hypotheses were tested at 0.05 alpha level.

$\mathrm{HO}_{1}$ : There is no significant relationship between consciousness about EE in senior secondary school curriculum and attitude toward the environment among senior secondary school students in Kwara.

$\mathrm{HO}_{2}$ : There is no significant relationship between male students' consciousness about EE concepts in chemistry curriculum and male students' attitude toward the 
environment among senior secondary school students in Kwara.

$\mathrm{HO}_{3}$ : There is no significant relationship between consciousness about EE concepts in chemistry curriculum and attitude toward the environment among SS1, SS2, and SS3 senior secondary school students in Kwara.

\section{Participants}

The population consist of all senior secondary school science students from the 18 senior secondary schools. The reason being that they are the students who have been taught EE. Four hundred students were approached for inclusion.

\section{METHODOLOGY}

The study utilized a descriptive survey design approach. As noted, the target population for the study was all senior secondary school science students. Simple random sampling technique was used to get the sample while stratified proportionate sampling technique was used to classify the population of the schools into three educational zones in the Kwara state (Crossman, 2020). The "Students' Attitude to Environment" (SAEQ) and "Students' Consciousness towards Environment" (SCEQ) survey instruments were developed by the researcher. Face and content validity of the questionnaires were validated by three experts from three different universities and the reliability of the instruments was conducted within the population of the study. Copies of questionnaires were administered by the researcher alongside a trained assistant to facilitate a higher response rate, which was done over a 4-week time period. Mean and standard deviation were used to analyze the research questions, inferential statistics of Pearson product moment correlation (PPMC) was used to test the null hypothesis.

\section{RESULTS}

RQ1: Would there be any relationship between consciousness about EE concepts in senior secondary school chemistry curriculum and attitude of chemistry students towards the environment in Kwara? (Table 1)

RQ2: Is there any relationship between male consciousness about EE concepts in chemistry curriculum and male attitude toward the environment among in senior secondary school students in Kwara?

\section{Testing of Null Hypotheses}

There was no significant relationship between consciousness about EE in senior secondary school curriculum and attitude toward the environment among senior secondary school students in Kwara.

This null hypothesis was tested using PPMC coefficient and the result of the analysis is summarized in Table 2.

Table 2 indicates a correlation between students' consciousness about EE and attitude toward the environment among senior secondary school students in chemistry. The result

\begin{tabular}{|c|c|c|c|c|c|c|}
\hline \multirow[t]{2}{*}{ Items } & \multicolumn{3}{|c|}{ Consciousness } & \multicolumn{3}{|c|}{ Attitude } \\
\hline & Mean & SD & Decision & Mean & SD & Decision \\
\hline Statement 1 & 4.25 & 0.990 & Agreed & 3.49 & 1.248 & Disagreed \\
\hline Statement 2 & 4.08 & 0.963 & Agreed & 3.50 & 1.231 & Agreed \\
\hline Statement 3 & 4.15 & 0.912 & Agreed & 3.44 & 1.234 & Disagreed \\
\hline Statement 4 & 4.01 & 1.027 & Agreed & 3.61 & 1.208 & Agreed \\
\hline Statement 5 & 4.20 & 0.866 & Agreed & 3.33 & 1.300 & Disagreed \\
\hline Statement 6 & 4.21 & 0.926 & Agreed & 3.51 & 1.215 & Agreed \\
\hline Statement 7 & 3.96 & 1.062 & Agreed & 3.61 & 1.259 & Agreed \\
\hline Statement 8 & 4.22 & 0.738 & Agreed & 3.47 & 1.272 & Disagreed \\
\hline Statement 9 & 4.23 & 0.894 & Agreed & 3.51 & 1.228 & Agreed \\
\hline Statement 10 & 4.20 & 1.003 & Agreed & 3.41 & 1.236 & Disagreed \\
\hline Statement 11 & 4.12 & 1.000 & Agreed & 3.47 & 1.203 & Disagreed \\
\hline Statement 12 & 4.28 & 0.891 & Agreed & 3.42 & 1.253 & Disagreed \\
\hline Statement 13 & 4.21 & 0.968 & Agreed & 3.32 & 1.287 & Disagreed \\
\hline Statement 14 & 4.16 & 0.998 & Agreed & 3.50 & 1.276 & Agreed \\
\hline Statement 15 & 4.06 & 1.035 & Agreed & 3.61 & 1.200 & Agreed \\
\hline Statement 16 & 4.28 & 0.918 & Agreed & 3.61 & 1.187 & Agreed \\
\hline Statement 17 & 4.11 & 1.001 & Agreed & 3.43 & 1.217 & Disagreed \\
\hline Statement 18 & 4.34 & 0.876 & Agreed & 3.61 & 1.212 & Agreed \\
\hline Statement 19 & 4.25 & 0.927 & Agreed & 3.34 & 1.192 & Disagreed \\
\hline Statement 20 & 4.20 & 0.924 & Agreed & 3.50 & 1.294 & Agreed \\
\hline Statement 21 & 4.20 & 0.935 & Agreed & 3.50 & 1.276 & Agreed \\
\hline Statement 22 & 4.21 & 0.968 & Agreed & 3.46 & 1.267 & Disagreed \\
\hline Statement 23 & 4.23 & 0.974 & Agreed & 3.52 & 1.24 & Agreed \\
\hline Statement 24 & 4.22 & 0.988 & Agreed & 3.48 & 1.178 & Disagreed \\
\hline Statement 25 & 4.25 & 0.944 & Agreed & 3.36 & 1.211 & Disagreed \\
\hline $\begin{array}{l}\text { Grand } \\
\text { mean }(\bar{X})\end{array}$ & 4.18 & & & 3.33 & & \\
\hline
\end{tabular}

Table 2: Pearson product moment correlation of students' consciousness about environmental education and attitude toward the environment among senior secondary school students

\begin{tabular}{lcccccc}
\hline Variable & $\mathbf{n}$ & Mean & SD & r-value & $\mathbf{r}^{2}$ & $\rho$-value \\
\hline Consciousness & 200 & 104.56 & 12.170 & 0.899 & 0.808 & $0.000^{*}$ \\
Attitude & 200 & 87.21 & 12.578 & & & \\
\hline
\end{tabular}

*Significant at $\rho<0.05$

revealed that the mean and standard deviation of students' consciousness about EE were 104.56 and 12.170 while the mean and standard deviation of students' attitude toward the environment among senior secondary school students in chemistry are 87.21 and 12.578 . The r-calculated $=0.899$, $\mathrm{r}^{2}=0.808, \mathrm{n}=200$, and $\rho=0.000$ which is $<0.05$ alpha value, on this basis, hypothesis one was rejected. Therefore, there was a positive correlation between the students' consciousness about EE and attitude toward the environment among senior secondary school students in chemistry. This implies that with $\mathrm{r}^{2}=0.808$, there was about $80.82 \%$ correlation between the students' consciousness about EE and attitude toward 
the environment among senior secondary school students in chemistry.

Hypothesis Two: There is no significant relationship between male consciousness about EE concepts in chemistry curriculum and male attitude toward the environment among senior secondary school students in Kwara.

This null hypothesis was tested using PPMC coefficient and the result of the analysis is summarized in Table 3.

Table 3 indicates a correlation between male consciousness about EE concepts in chemistry curriculum and male attitude toward the environment among senior secondary school students in chemistry. The result revealed that the mean and standard deviation of male consciousness about EE were 104.233 and 11.149 while the mean and standard deviation of male attitude toward the environment in chemistry were 85.38 and 10.001. The r-calculated $=0.933, \mathrm{r}^{2}=0.870, \mathrm{n}=86$, and $\rho=0.000$ which is $<0.05$ alpha value, on this basis, hypothesis two was rejected. Therefore, there was a positive correlation between male consciousness about EE concepts in chemistry curriculum and male attitude toward the environment among senior secondary school students in chemistry. This implies that with $r^{2}=0.870$, there was about $87.04 \%$ correlation between the male consciousness about EE concepts in chemistry curriculum and male attitude toward the environment among senior secondary school students in chemistry.

Hypothesis 3: There is no significant difference between consciousness about EE concepts in chemistry curriculum and attitude toward the environment among SS1, SS2, and SS3 senior secondary school students in Kwara.

Analysis of variance (ANOVA) was used to test the null hypothesis and the summary of the results is presented in Table 4.

Table 4 shows the summary of ANOVA results of students' responses between consciousness about EE concepts in chemistry curriculum and attitude toward the environment among SS1, SS2, and SS3 senior secondary school students in Kwara. This table revealed that $F(1.423)=10.026, \rho=0.002$ at $\rho<0.05$. On this basis, hypothesis three was rejected. Therefore, there was a statistically significant difference between consciousness about EE concepts in chemistry curriculum and attitude toward the environment among SS1, SS2, and SS3 senior secondary school students in Kwara.

\section{DISCUSSION OF THE FINDINGS}

The result from hypothesis one showed that there was a high correlation between the students' consciousness about EE and attitude toward the environment among senior secondary school students toward the environment in Kwara. This finding agrees with Abdul-Wahab (2008) who conducted a preliminary investigation into the environmental consciousness of the Omani public and their willingness to protect the environment. The focus of this study was to investigate the students' level

\begin{tabular}{|c|c|c|c|c|c|c|}
\hline Variable & $n$ & Mean & SD & r-value & $r^{2}$ & $\rho$-value \\
\hline $\begin{array}{l}\text { Male } \\
\text { consciousness }\end{array}$ & 86 & 104.23 & 11.149 & 0.933 & 0.870 & $0.000 *$ \\
\hline Male attitude & 86 & 85.38 & 10.001 & & & \\
\hline
\end{tabular}

*Significant at $\rho<0.05$

\begin{tabular}{|c|c|c|c|c|c|}
\hline Group & $\begin{array}{l}\text { Sum of } \\
\text { square }\end{array}$ & df & $\begin{array}{l}\text { Mean } \\
\text { square }\end{array}$ & $F$ & $\rho$-value \\
\hline $\begin{array}{l}\text { Between } \\
\text { group }\end{array}$ & $53,684.820$ & 5 & $10,736.964$ & 115.296 & $0.000^{*}$ \\
\hline $\begin{array}{l}\text { Within } \\
\text { group }\end{array}$ & $36,691.278$ & 394 & 93.125 & & \\
\hline Total & $90,376.098$ & 399 & & & \\
\hline
\end{tabular}

*Significant at 0.05 level

of consciousness about environmental issues and to find out their environmental attitudes and behaviors toward their environment. The results of the survey showed that these students were consciousness about environmental problems, but that they lacked general knowledge about environmental issues. This study also revealed that the students achieved a higher score in their environmental attitudes than in their environmental behaviors.

The result from hypothesis three revealed that there was a significant difference between consciousness about EE concepts in chemistry curriculum and attitude toward the environment among SS1, SS2, and SS3 students in Kwara. However, this finding agreed with the findings of Chinedu (2008) who found that class has a significant different on students' environmental consciousness and attitude in Owerri and Okigwe education zones in Imo state. In view of this argument, the United Nations Development Project (UNDP, 2010) explained that environmental consciousness and attitude of people was directly proportional to the quality and quantity of information available to them in their classroom or location.

\section{RECOMMENDATIONS}

Based on the findings of this study, the following recommendations are made:

1. This study found out that though students in senior secondary schools were aware of several environmental concepts and problems, it was found that there was an 
inadequate level of consciousness of current and emergent environmental problems. Environment and environment problems are dynamic and emergent. As a result, if the content which the students interact with is not regularly updated, there is a probability that students will not interact with the environmental issues that are of concern.

2. Having investigated the level of consciousness of students in Kwara on both new and current environmental problems and concepts, it is recommended that the Ministry of Education updates the curriculum of senior secondary school particularly of subjects (e.g., chemistry and biology) managing EE content to reflect the current and developing environmental concepts and problems. This will make learning of EE more relevant in achieving its objectives.

\section{CONCLUSION}

Based on the evidence of this study's findings, students possessed inadequate attitudes toward the environment. It could be argued that the students' environmental consciousness influenced their attitude toward the environment. Furthermore, continued existence and well-being of all living things, plants, and animals depend to a large extent on the ability of humankind to enhance, protect, conserve, and manage the natural resources in the environment. These life supporting means are threatened by natural and anthropogenic challenges or a combination of the two. In Kwara, different environmental problems are associated with various erosion, leaching, pollution, climatic, vegetation, and geologic zones. As it had been emphasized, the quality of instruction in schools depends much on the quality of EE impacted to students.

\section{REFERENCES}

Abdullah, A. (2009). Science Teaching in Nigeria. Ilorin: Atoto Press.

Abdul-Wahab, S.A. (2008). Investigation into environmental awareness in Omani public schools and their attitudes to environment. American Journal of Environmental Education, 4(1), 39-49.

Adelagan, J.A. (2016). The History of Environmental Science and Pollution of Water Sources in Nigeria (1960-2016). The Way Forward, Research Report No. 2 Development Policy. Nigeria: Macmillan Nigeria Publishers.
Adedayo, A., \& Olawepo, J.A. (1997). Integration of environmental in social science curricula at the secondary school level in Nigeria problems and prospects. Environmental Education Research, 3(1), 83-93.

Aina, T.A. (2012). Environmental Perception and Human Behaviour: Modules 3. Some Secondary Schools in Kaduna and Jama's Education Zone of Kaduna State. (Unpublished Master of Education Thesis. University of Nigeria, Nsukka).

Chinedu, C. (2008). Environmental education awareness of attitudes of secondary school students in Owerri Education Zone, Imo state. (Unpublished Master of Education Thesis of the Department of Science Education, UNN).

Crossman, A. (2020). Understanding Stratified Samples and how to Make Them. Available from: https://www.thoughtco.com/stratified-sampling-3026731.

Jekayinfa, A.A., \& Yusuf, A. (2004). An investigation into student teacher views on the introduction of environmental education into the Nigeria social studies curriculum. Journal of Studies in Education, 2, 1-8.

Kwara State Waste Management Council. (2007). $2^{\text {nd }}$ Phase of Green/CleanCampaign Booklet. Nigeria: Kwara State Government.

Manahan, S.E. (2006). Environmental Science and Technology: As Sustainable Approach to Green Science and Technology. $2^{\text {nd }}$ ed. Milton Park: Taylor and Francis.

Nigeria Demographic and Health Survey. (2004). Health and Sanitation in Developing Countries. World Health Report 2005.

Olusanya, A. (2006). Effects of educational background on students' attitudes, activity levels, and knowledge concerning the environment. Journal of Environmental Education, 31(3), 12-19.

Ononugbo, F.C. (2005). Climate change and national security: Exploring the conceptual and empirical connections in Nigeria. Journal of Sustainable Development in Africa, 12(4), 255-269.

Toili, W.W. (2007) Secondary school students' participation in environmental action coercion or dynamism? Eurasia Journal of Mathematics Science and Technology Education, 3(1), 51-69.

United Nation Education Scientific Cultural Organization. (2005). Climate change, impacts. In: Adaptation and Mitigation of Climate Change. Cambridge: Cambridge University Press.

United Nation Education Scientific Cultural Organization. (2007). $4^{\text {th }}$ Intergovernmental Conference on Environmental Education. Available from: https://www.unevoc.unesco.org/home/4th\%20International $\% 20$ Conference $\% 20$ on\%20Environmental\%20Education $\% 20$ in $\% 20$ Ahmedabad,\%20India.

United Nations Development Programme. (2010). UN Decade of Education for Sustainable Development 2005-2010 Intervention Implementation Scheme. Available from: https://www.en.unesco.org/themes/educationsustainable-development.

United Nations Environmental Programme. (2012). 21 Issues for the 21 ${ }^{\text {st }}$ Century: Result of the UNEP Foresight Process on Emerging Environmental Issues. United Nations: United Nations Environment Programme.

World Commission for Environment and Development. (2018). Our Common Future World Commission on Environmental and Development. Oxford: Oxford University Press. 